\title{
Stimulasi Perilaku Sosial Anak Usia Dini melalui Media Loose Parts (Bahan Lepasan)
}

\author{
Wahju Dyah Laksmi Wardhani ${ }^{\circledR}{ }^{\bowtie}$, Misyana $^{2}$, Ika Atniati $^{3}$, Nina Septiani $^{4}$ \\ Pendidikan Guru Pendidikan Anak Usia Dini, Universitas Muhammadiyah Jember \\ DOI: $10.31004 /$ obsesi.v5i2.694
}

\begin{abstract}
Abstrak
Bahan lepasan atau yang lebih dikenal sebagai loose parts merupakan media pembelajaran yang memberi anak kesempatan untuk mengeksplorasi, memanipulasi, atau mengeksploitasi imajinasi secara kritis, karena karaktersitik loose parts yang memungkinkan anak mengolah sesuai bentuk dari ide yang dipikirkannya. Artikel ini bertujuan untuk mendeskripsikan bagaimana bahan lepasan sebagai media belajar tidak saja hanya mengajarkan anak mewujudkan suatu imajinasi melalui metode proyek, namun juga melatih anak dalam pengembangan aspek sosialnya. Subyek dalam penelitian ini adalah anak-anak kelompok A di TK Bukit Aksara Semarang. Penelitian ini penelitian kualitatif yang menerapkan perspektif fenomenologis. Kesimpulannya, bentuk-bentuk perilaku sosial seperti kerja sama, kemandirian, tanggung jawab dan percaya diri nampak saat anak bermain mengolah bahan lepasan. Hasil ini penelitian ini dapat menjadi rujukan bagi guru PAUD untuk menggunakan bahan lepasan ke dalam kurikulum.
\end{abstract}

Kata Kunci: bahan lepasan; perilaku sosial; anak prasekolah

\begin{abstract}
Loose parts were learning media which gave the children a chance for exploring, manipulating, or exploitating the imagination critically because its characteristics enable them to proccess and shape according to their idea. The aim of this paper was to describe how the loose parts could be used as a learning media, not only taugh the children about imagination through project method but also trained the children to develop theie social aspect. The subjects were the children from group A in TK Bukit Aksara Semarang. This research was qualitative with phenomenology approach. The finding of this study demonstrated that the social skills like cooperation, independence, responsibility, and self convidence seen when the children played and proceed the loose parts. It could be used as a guiding for preschool teacher to use the loose part into the curriculum.
\end{abstract}

Keywords: loose parts; social behaviour; preschool

Copyright (c) 2021 Wahju Dyah Laksmi Wardhani, Misyana, Ika Atniati, Nina Septiani

$\triangle$ Corresponding author :

Email Address : dyahlaksmi_paud@unmuhjember.ac.id (Jember, Indonesia)

Received 5 August 2020, Accepted 13 December 2020, Published 3 February 2021 


\section{PENDAHULUAN}

Manusia adalah makhluk sosial yang artinya seseorang tidak dapat lepas dari lingkungan sosial yang ada di sekelilingnya. Kemampuan bersosialisasi manusia dilatih dan diasah sejak manusia dilahirkan ke dunia. Manusia mulai bersosialisasi melalui interaksi dengan manusia yang paling dekat dengannya sejak dia lahir yaitu orang tua. Interaksi ini sebenarnya terjalin secara instingtif namun seiring berjalannya waktu seorang bayi bertumbuh kembang menjadi seorang dan keluarga berfungsi sebagai penyedia pijakan tumbuh kembang kemampuan sosialnya. Bolwby mengaji hal ini dari sisi kemelekatan yang dibangun antara orang tua dan anak sebagai suatu akibat pola pengasuhan yang diterapkan. (Henniger, 2013). Artinya, seorang bayi belajar mengembangkan refleknya untuk membangun hubungan sosial dari perilaku, entah yang baik atau kurang baik, yang diterapkan oleh orang tua dan keluarga besarnya.

Seiring tumbuh kembang, seorang anak melangkah keluar dari keluarganya untuk berinteraksi dengan lingkungan sosial di luar keluarga batih maupun keluarga besarnya. Pada masa sekarang lingkungan sosial di luar keluarga tidak selalu berarti lingkungan tempat tinggal anak, melainkan bisa tempat anak belajar atau tempat anak dititipkan sementara waktu karena orang tua yang harus bekerja. Seorang anak memerlukan adaptasi ketika berada di lingkungan fisik dan lingkungan sosial yang baru. Hal ini kadang bukan menjadi suatu tindakan yang mudah untuk dilakukan oleh seorang anak yang pada kemampuan berpikirnya masih terbatas.

Saat berinteraksi di luar keluarga, anak mempelajari aturan-aturan baru, kebiasaankebiasaan rutin baru, orang dewasa baru dan teman-teman sebaya yang sebelumnya tidak dikenal. Ada anak yang mampu beradaptasi dan berinteraksi dengan cepat dengan lingkungan sosial yang baru tersebut. Namun tidak sedikit pula anak yang mengalami kesulitan dalam beradaptasi sehingga kondisi menjadi masa yang sulit bagi anak, orang tua maupun lembaga dimana anak menjadi anggota baru. Penelitian tentang bagaimana perkembangan kemampuan anak bersosialisasi telah dikaji secara luas. Hasil penelitian yang meneliti 14 artikel menemukan bahwa kelas yang multikultur memberi suasana positif untuk mengembangkan keterampilan anak bersosialisasi (Khalfaoui et al., 2021). Perubahan lingkungan sosial membentuk masa transisi yang mempengaruhi kondisi sosial emosional anak dikaji oleh Pirskanen, Jokinen dan kawan-kawan

Pentingnya membangun suasana belajar yang sebagai pijakan anak belajar tentang aturan baru, berkenalan dengan wajah-wajah baru menjadi pertimbangan yang mendasar saat menyiapkan kegiatan untuk anak. Anak belajar dengan baik dan belajar tentang banyak hal, khususnya berkenalan dengan lingkungan sosial baru, melalui kegiatan bermain. Anak yang memasuki PAUD berada pada tahap perkembangan kognitif praoperasional, yang salah satu cirinya adalah egosentris (Henniger, 2013). Karakteristik egosentris pada tahap perkembangan kognitif yang praoperasional menyebabkan anak sulit menerima sudut pandang atau pendapat atau tindakan orang lain. Namun demikian hasil study membuktikan bahwa bermain bersama dengan teman yang dikondisikan secara berulang dapat membangun pengetahuan dan keterampilan berinteraksi sosial pada anak (Sari et al., 2019).

Perilaku manusia menandai interaksi yang terjadi antara manusia dengan lingkungannya, baik lingkungan fisik maupun sosial. Kadang-kadang terdapat perilaku anak saat berinteraksi dengan teman atau orang dewasa yang dianggap tidak baik sehingga orang dewasa akan menegur dan menunjukkan contoh perilaku yang benar. Di suatu keluarga yang sedang menerima tamu, kemudian anak mengganggu orang tua dengan meminta perhatian yang dianggap orang dewasa berlebihan, maka bisa jadi anak dianggap sebagai anak yang rewel atau manja. Saat sedang belajar di kelas, seorang anak tidak dapat berhenti berlari-lari di dalam kelas, meskipun tidak mengganggu temannya namun hal ini dianggap oleh teman atau guru sebagai perilaku yang mengganggu suasana belajar. Penelitian menunjukkan bahwa mengklarifikasi bahwa perkembangan anak ditandai oleh keinginan untuk bermain bersama temannya (Pebriana, 2017). 
Perilaku merupakan segala bentuk gerak, tindakan, atau fungsi yang dilakukan oleh seseorang yang terjadi dan berakibat pada perubahan lingkungan fisik seseorang tersebut (Casey \& Carter, 2016). Oleh karenanya kegiatan berpikir yang tidak disertai dengan tindakan seseorang tidak dapat disebut sebagai perilaku. Sebaliknya, kesedihan atau kemarahan yang terjadi karena dipicu perubahan situasi dan kondisi di lingkungan seseorang, dapat disebut sebagai perilaku. Fungsi perilaku seseorang dapat dilihat terhadap perubahan yang bersifat efektif dan efisien pada lingkungan seseorang.

Perilaku yang dilakukan oleh seseorang dalam interaksi sosial didasari oleh suatu alasan. Alasan yang paling sering dikemukakan mengapa perilaku dilakukan seseorang adalah karena orang tersebut merespon perilaku dari lingkungan untuk membalas perilaku lain sebelumnya. Cooper, Heron dan Heward menyebutkan ada dua kategori perilaku yaitu penguatan perilaku yang positif dan penguatan perilaku yang negatif (Casey \& Carter, 2016). Penguatan positif terjadi ketika seseorang mendapatkan penguatan untuk berperilaku agar mendapatkan jalan meraih sesuatu, sedangkan penguatan yang negatif adalah perilaku seseorang ketika ingin keluar atau menghindar dari suatu situasi atau kondisi.

Saat anak memasuki lingkungan fisik dan sosial baru di luar keluarga, anak akan mengalami masa adaptasi saat berinteraksi sosial. Penguatan positif maupun negatif akan menjadi proses latihan yang dijalani anak guna memahami nilai-nilai, aturan-aturan, atau pandangan yang berbeda sebagai alasan untuk dia berperilaku guna meraih tujuannya atau meninggalkan kondisi yang tidak disukai atau diharapkan. Kemampuan anak memiliki kesadaran atau sensitivitas untuk berperilaku menyesuaikan diri dengan lingkungan saat berinteraksi hingga perilakunya dapat diterima oleh orang di sekitarnya ini yang disebut sebagai perilaku sosial. Perilaku sosial yang berpenguatan positif dikenal sebagai perilaku prososial. Honig dan Wittmer menyebutkan bahwa guru PAUD dapat merancang kegiatan bermain agar anak memiliki perilaku prososial, yang ditandai oleh beberapa karakteristik seperti: menekankan kerja sama, mengajarkan resolusi konflik, membuat invitasi yang memungkinkan anak bekerja kelompok, berdiskusi yang mengarahkan padan interaksi sosial yang positif (Henniger, 2013).

Tidak semua orang tua mengajarkan aturan atau pembisaan perilaku sosial yang dapat diterima semua pihak. Sebagian orang tua bahkan beranggapan perilaku negative anak merupakan hal yang wajar bagi anak usia dini. Ada juga orang tua yang beranggapan anak akan belajar bersosialisasi memahami pandangan dan tindakan orang lain seiring pertambahan usia (matang) dan perkembangan kemampuan berpikirnya. Hal ini yang menjadi landasan mengapa proses pembelajaran di PAUD dirancang untuk melatih dan membiasakan anak berperilaku sosial yang dapat diterima oleh semua pihak. Di samping itu, pembelajaran juga dirancang agar anak dapat memahami sudat pandang dan tindakan orang lain. Tujuan dari pengenalan dan pembiasaan itu adalah agar seiring dengan perkembangan kemampuan berpikir anak yang semakin matang juga memiliki perilaku yang dalam tatanan nilai masyarakat dapat diterima sebagai perilaku sosial yang positif.

Kajian ini hendak memaparkan proses interaksi sosial yang terjadi ketika anak bermain untuk belajar di Kelompok A TK Bukit Aksara. Sebagai satuan PAUD yang mengadopsi model pembelajaran Reggio Emilia, TK Bukit Aksara melaksanakan proses pembelajaran dengan metode proyek berbasis bahan lepasan atau yang dikenal sebagai loose parts. Setting belajar menggunakan bahan lepasan otentik ini diawali dengan invitasi yang dibuat oleh guru berdasarkan inisiasi dari buku cerita yang dibacakan sesuai pilihan anak. Kegiatan ini dilaksanakan saat minggu awal pembelajaran.

Guru menata invitasi dari bahan lepasan di beberapa tempat, bahkan ada yang di luar kelas atau di area terbuka (outdoor) sebelum kegiatan pembelajaran. Anak dapat mengeksplorasi, mengeksploitasi maupun memanipulasi inivitasi baru atau melanjutkan proyek yang sudah dibuat dengan menambahkan dari materi invitasi atau dari media yang tersedia di atelier. Penelitian Wahyuni menjelaskan peran loose parts sebagai media yang 
menyebabkan anak menjadi biasa berpikir secara kreatif dan kritis untuk dapat menyajikan produk yang terbaik (Wahyuningsih et al., 2017)

Pada saat anak bermain, tak jarang terjadi interaksi yang berkembang untuk mewujudkan proyek yang disepakati bersama. Bahan lepasan menjadi media anak menunjukkan perilaku sosialnya, baik yang bisa diterima atau menimbulkan ancaman konflik saat bermain bersama. Bahan lepasan atau loose parts merupakan semua bentuk benda yang dapat dimainkan, diteliti dan dimanipulasi anak yang diperoleh anak dari lingkungan di sekitarnya. Sedangkan Haughey menyatakan bahan lepasan sebagai bahan yang terbuka,dapat dipisahkan namun dapat pula dikombinasikan dengan materi lain, dapat dipindahkan, dijajarkan atau digabungkan dengan materi lain (Siantajani, 2020). Artikel ini akan menguraikan bagaimanakah anak menggunakan bahan lepasan sebagai media untuk mengembangkan perilaku sosial dalam berinteraksi dengan teman? Bentuk-bentuk perilaku sosial apa yang muncul saat anak bermain dengan media bahan lepasan tersebut? Artikel ini akan menguraikan lebih lanjut.

\section{METODOLOGI}

Kajian ini merupakan penelitian kualitatif fenomenologis, yang bertujuan untuk memaparkan fakta-fakta yang diperoleh dari hasil pengamatan dan dokumentasi serta ditunjang dengan wawancara guna mendapatkan pemaknaan yang tepat dari subyek penelitian. Metode penelitian ini dipilih karena data yang akan dikumpulkan berupa fakta yang terjadi lapangan dan jelas terlihat. Data tersebut berupa hasil pengamatan terhadap perilaku sosial yang muncul anak ketika menggunakan bahan lepasan.

Subyek dalam penelitian ini sebanyak 13 anak. Mereka adalah peserta didik kelompok A yang berusia 4-5 tahun di TK Bukit Aksara. Informan kunci dalam penelitian ini adalah kepala sekolah TK Bukit Aksara dan guru kelas kelompok A. Keduanya disebut sebagai Ibu Kasek dan Ibu Guru dalam artikel ini.

Teknik pengambilan data yang digunakan dalam penelitian ini adalah observasi, wawancara, dan dokumentasi. Observasi atau pengamatan terhadap anak untuk mengetahui perilaku sosial yang muncul ketika bermain loose parts. Wawancara digunakan untuk memperoleh data tentang persiapan guru ketika akan bermain loose parts dan mencocokkan data hasil observasi. Sedangkan dokumentasi untuk menunjang kedalaman makna narasi dan memudahkan memahami konteks fakta yang diceritakan. Sebelum digunakan, instrumen penelitian yakni lembar observasi, pedoman wawancara, dan pedoman dokumentasi terlebih dahulu divalidasi oleh dua pakar yakni kepala sekolah dan dosen.

Data yang terkumpul berupa narasi singkat yang diperoleh melalui lembar observasi. Sedangkan narasi berupa kalimat panjang diperoleh dari hasil wawancara guru dan kepala sekolah. Dokumentasi menghasilkan data berupa foto kegiatan anak ketika menggunakan benda-benda loose parts. Selain foto, rekaman video kegiatan anak di kelas juga terdokumentasikan.

Kesahihan data dilakukan dengan menggunakan uji trianggulasi teknik yang dilakukan dengan dua langkah. Pertama, mengecek fakta dari hasil pengamatan, hasil wawancara dengan informan kunci, dan dokumentasi foto. Keajegan pernyataan yang diperoleh dari foto dan catatan lapangan ditanyakan pada guru kelas, dan mendiskusikan kembali dengan kepala sekolah dan pakar (dosen pembimbing). Cara kedua, bertukar informasi dengan sejawat yang mengamati pada kelas yang berbeda tentang kejadian sejenis serta menemukan kesamaan fakta dari video yang didokumentasikan, yang kemudian dicatat dalam jurnal harian untuk didiskusikan dengan pembimbing yang bertindak sebagai pakar. Proses analisis data dapat dilillhat pada Gambar 1. 


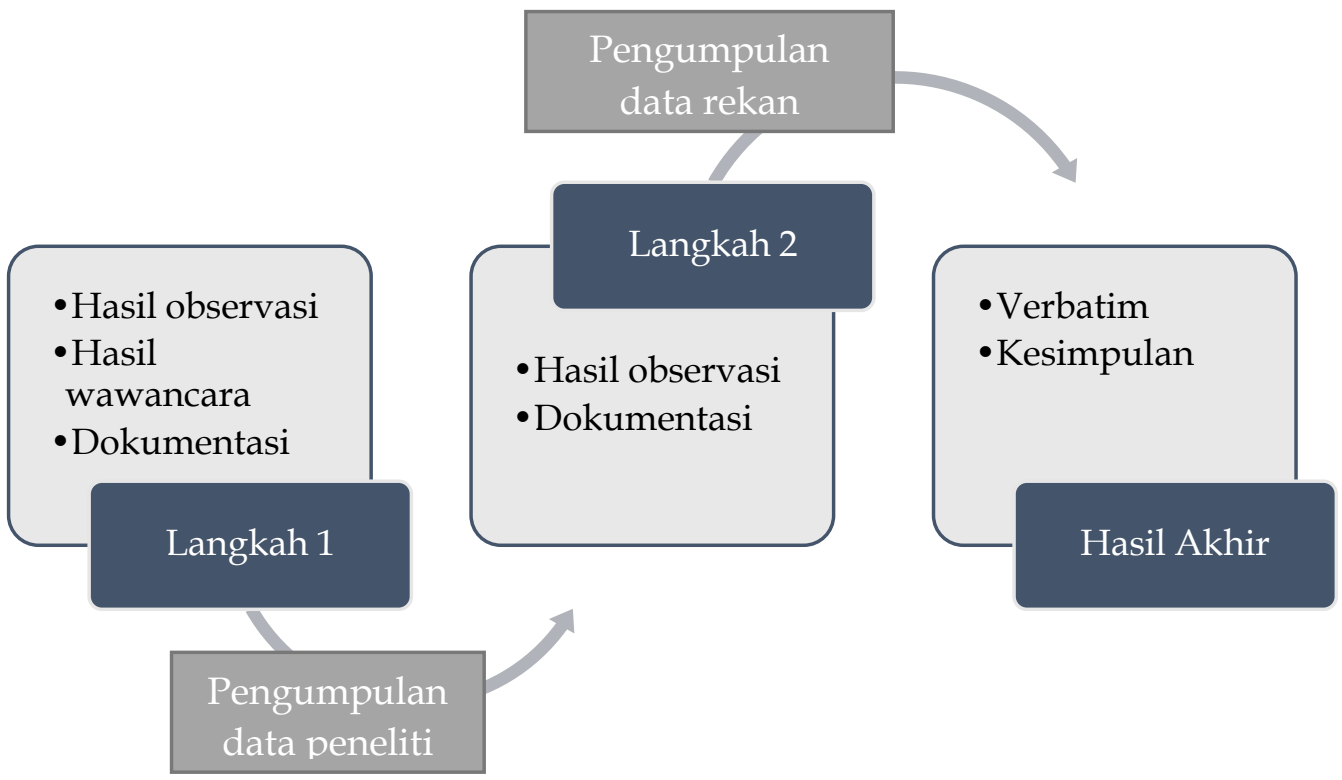

Gambar 1. Proses Analisis Data Penelitian

\section{HASIL DAN PEMBAHASAN}

\section{Invitasi dan bahan lepasan sebagai media berinteraksi sosial}

Guru-guru di Taman Kanak-Kanak Bukit Aksara (selanjutnya ddisebut TK Bukit Aksara) mengawali kegiatan sejak sebelum jam belajar dimulai dengan menyiapkan invitasi. Guru merancang invitasi berdasarkan hasil diskusi dengan anak-anak pada saat sebelum jam belajar berakhir sehari sebelumnya. Invitasi bertujuan untuk mengundang anak memperkaya hasil karya yang sudah dibuat atau proyek baru yang direncanakan hari itu dengan menggunakan berbagai bahan lepasan (loose parts) yang disiapkan sekolah. Sebagian besar bahan lepasan ini bukan berbentuk benda jadi produk pabrik seperti banyak media bermain yang biasa ditemukan di sekolah, seperti mobil-mobilan, alat masak-masakan, alat dokterdokteran.

Guru biasanya menyiapkan invitasi dengan menggabungkan beberapa jenis bahan lepasan atau dari bahan lepasan sejenis namun beragam materi asalnya. Invitasi dengan bahan lepasan yang beragam jenis dapat berupa gabungan antara kayu, bahan alam, invitasi bisa ditata di dalam ruang kelas, atau di luar kelas, atau bahkan di halaman sekolah. Tatanan invitasi harus dibuat semenarik mungkin sehingga menggugah perhatian dan kreativitas anak untuk menggunakannya. Bahan lepasan yang digunakan sebagai invitasi juga tidak selalu harus diwadahi. Bisa saja bahan lepasan itu seperti digeletakkan begitu saja, disandarkan atau ditata berdampingan dengan jenis bahan yang berbeda.

Bahan lepasan tidak selalu berupa benda tak jadi seperti beragam jenis lempeng kayu atau potongan bambu, gelondongan kertas atau spul plastik, atau beragam kancing dan batubatuan, baik yang dari plastik atau batu asli, atau beragam jenis kerang-kerangan atau bijibijian. Bahan lepasan juga dapat berupa benda-benda buatan pabrik yang dapat dimanfaatkan anak karena sesuai fungsinya, namun bukan berbentuk mainan jadi macam alat masakmasakan, alat dokter-dokteran atau alat pertukangan yang terbuat dari plastik. Contoh benda tersebut dapat dilihat pada gambar 2. Benda-benda buatan pabrik itu merupakan benda sesungguhnya yang masih dapat difungsikan, bukan benda yang rusak atau tak terpakai. Benda-benda ini seperti berbagai macam alat pertukangan, alat elektronik, dan beragam alat yang memiliki fungsi khusus seperti stetoskop, teleskop, mikroskop atau ember dan timba beragam. 


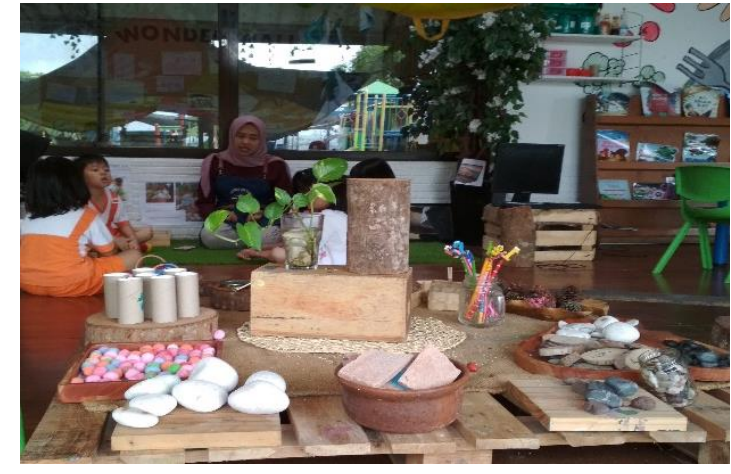

Gambar 2. Invitasi dengan jenis bahan lepasan yang berbeda (dokumen penelitian)

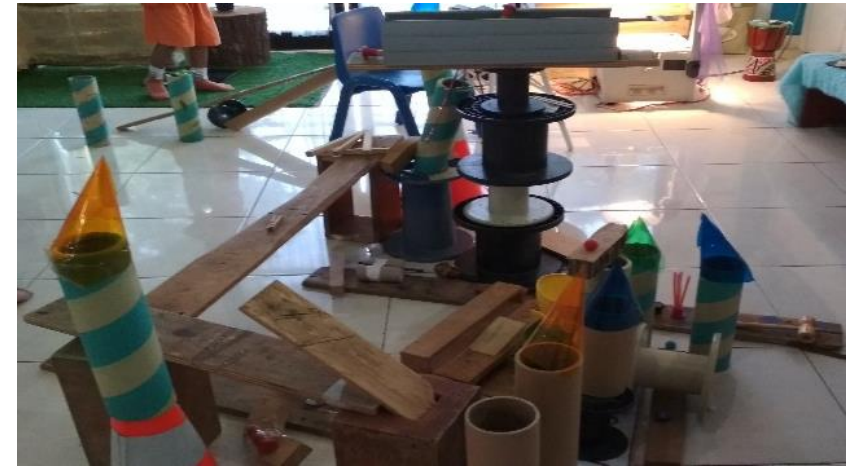

Gambar 3. Salah satu struktur skybridge (dokumen penelitian)

Pagi itu pada hari Senin, sebagian besar anak kelompok TK A masih berniat untuk melanjutkan proyek yang telah dikerjakan pada minggu sebelumnya. Ibu Guru menata invitasi sesuai dengan masukan dari anak-anak sebelum libur akhir pekan. Di dalam kelas, Ibu guru menata invitasi semacam meja rias dengan peralatan make up dan ada semacam krayon besar. Ibu guru menjelaskan, "Ini krayon untuk wajah" sambil tersenyum. Di pojok dekat jendela atau pintu kaca besar, Ibu guru menata di meja beberapa potongan kayu dan ranting pohon yang mulai mengering. Di dekat tempat itu ada potongan tebal kayu yang dipotong melintang, ada jamur di atas penampangnya. Di sebelah potongan batang kayu, Ibu guru menyandarkan 3 lempeng kayu dengan panjang sekitar 1 meter pada meja plastic pendek. Di belakang meja tersandar teropong besar, yang jelas asli. Di bawahnya tergeletak peralatan tukang asli seperti obeng, palu, selotip besar. Juga ada alat pengering rambut (hairdryer) dan gelondong karton dengan ukuran antara 30 hingga $40 \mathrm{~cm}$.

Di pojok bagian depan kelas, di area kanan dan kiri, masih nampak tergeletak susunan balok-balok. Ada 3 bangunan yang berbeda bentuknya. Ibu Guru menjawab pertanyaan apa topik proyek ini, "Anak-anak minggu lalu sibuk membuat skybridge. Awalnya ada yang bercerita tentang saat liburan di luar negeri. Keluarganya makan di restoran di lantai atas hotel. Lalu teman-temannya penasaran seperti apa restoran di lantai atas hotel itu. Maka kami pun mencari di internet. Tapi kemudian ada restoran di atas skybridge. Nah, anak-anak tertarik membuat skybridge".

Guru meneruskan menata invitasi di arena luar kelas, di lobby sempit antara ruang kantor, atelier dan kelas. Di atas hamparan karpet, bu guru meletakkan gelondongan bekas tisu gulung yang dikombinasi dengan spul-spul kecil dan sedang. Minggu lalu tempat itu menjadi kendang unicorn. Cerita tentang unicorn memang terpisah dari cerita tentang skybridge. Kandang unicorn merupakan proyek sebagian besar anak perempuan. Meja rias dan pojok Kasur yang ada di dalam kelas merupakan bagian istana tempat putri yang memelihara unicorn. Ibu guru kembali tersenyum saat menjelaskan, "Anak-anak perempuan tertarik dengan cerita unicorn yang dimiliki oleh putri raja. Cuma kandang harus terpisah dari istana. Jadi mereka buat di sini".

Ibu guru menjelaskan kebanyakan anak akan mengakses secara bersama invitasi, meskipun nantinya bisa saja mengembangkan proyek lain seperti skybridge. Skybridge merupakan proyek individual sedangkan unicorn dan sirkuit (kayu yang disandarkan pada meja plastik itu ternyata untuk lomba balap mobil) merupakan proyek bersama. Contoh bangunan bisa dilihat pada Gambar 3. Anak-anak memiliki pilihan-pilihan sendiri. Ada kalanya seorang anak tidak fokus pada satu kegiatan atau memiliki proyek sendiri, dia cenderung sebagai follower pada kegiatan yang dikembangkan oleh temannya. Pada anak yang demikian, Ibu guru akan memberikan provokasi agar dia memiliki kegiatan yang menuntut kreativitas dan idenya. 
Ketika tiba waktu bermain, anak-anak memilih kegiatan bermainnya dan nampak terjadi apa yang disampaikan oleh Ibu Guru. Ada anak yang langsung bekerja dengan proyeknya yang tertunda, ada anak yang memilih permainan baru, juga ada anak yang nampaknya hanya mengikuti apa yang dilakukan temannya. Follower semacam ini nampak pada tindakan yang dilakukan. Anak ini berpindah-pindah tempat dan cenderung nampak tidak suka melakukan kegiatan yang diperintahkan oleh temannya yang lebih dulu terlibat dengan suatu permainan.

Secara umum pada minggu itu anak-anak masih bermain dengan proyek sebagaimana yang diceritakan oleh Ibu guru, meski juga proyek yang tidak dilanjutkan oleh anak-anak. Misalnya proyek membangun skybridge, dianggap tidak lagi menarik. Tiga orang anak yang bekerja pada proyek tersebut dan teman yang membantu menyatakan akan berganti dengan permainan baru. Dua orang anak memilih membuat proyek membangun yang berbeda sedangkan seorang anak memilih untuk bermain dengan teman-teman yang bermain balap mobil. Salah seorang dari anak memilih membangun masjid jami' Semarang, dan seorang lagi membangun technopark. Sebut saja nama anak yang akan membangun technopark itu adalah Julio.

Julio menjawab pertanyaan Ibu Guru apakah dia akan menambahkan beberapa benda untuk skybridge-nya, bahwa dia akan membangun yang lain. Julio akan membangun technopark Semarang seperti tempat yang sering dia kunjungi. Dia menggunakan beberapa bahan lepasan baru selain bahan yang sudah dipakai sebelumnya.

Awalnya Julio bekerja sendirian (lihat Gambar 4). Tak lama kemudian seorang teman perempuan datang menghampiri dan bertanya mengapa skybridge-nya dibongkar (lihat Gambar 5). Di tengah kesibukannya membangun, Julio menjawab akan membangun technopark. Sang teman bertanya lagi, technopark seperti yang aslinya? Julio menjawab singkat, "' He eh".

Sekelompok anak tampak asyik mengembangkan sirkuit. Kelompok ini mengakses invitasi yang dibuat Ibu Guru dengan menambahkan beberapa kayu tambahan atau ada yang dengan mencoba beberapa macam cara menjalankan mobilnya. Mereka tidak saling berebut kapan waktu akan menggelindingkan mobil. Semua anak bersepakat akan menunggu teman yang sudah berdiri di ujung paling atas sirkuit.

Interaksi yang terjadi antar anak berlangsung alami melalui kerja sama pada kegiatan yang sedang dimainkan. Masing-masing anak memiliki ide dan mereka mencoba mengeksplorasi ide-ide tersebut dengan melibatkan teman. Yang menarik, anak-anak sudah memiliki resolusi konflik bila terjadi ancaman konflik, yang biasanya dapat terjadi karena ide yang dimiliki tidak diakses oleh teman pada kelompok tersebut. Resolusi ini tampak telah terinternalisasi pada setiap anak adalah memberi kesempatan pada teman dengan membuat perjanjian nanti akan mencoba idenya. Anak yang belum mendapat kesempatan memanipulasi permainan sesuai idenya bahkan cenderung membantu teman yang mendapat kesempatan mencoba idenya terlebih dahulu. Seorang anak yang mengalami harus menunggu idenya untuk dicoba ketika ditanya dengan santai menjawab, "Nanti juga main. Sekarang Daniel (bukan nama sebenarnya) dulu. Gantian", sambil mengamati mobil yang diluncurkan dengan seksama dari atas kursi tempat kayu sirkuit disandarkan (lihat Gambar 6)

Tidak selalu anak yang hari ini bermain dengan kegiatan bersama akan mengakses kegiatan tersebut secara intens hingga berhari-hari. Ada sebagian anak yang memilih untuk memainkan invitasi lain atau berpindah dari satu kegiatan ke kegiatan lain mengingat waktu bermain yang panjang. Selama dua jam penuh anak memiliki kesempatan bermain dengan berbagai media baik yang ditata dalam invitasi atau mengakses dari atelier yang ada di sekolah.

Penambahan volume invitasi yang disiap-kan guru seringkali dapat memperkaya ide kreatif anak untuk menambah atau memperpanjang proyek yang sedang dikerjakan. Hal ini yang membuat interaksi dan sosialisasi yang terjalin antar anak dapat dengan mudah terjadi. 
Suatu material yang sederhana dan hanya merupakan bahan bekas ternyata dapat menjadi suatu karya unik yang menarik. Dari hasil dialog dan olah kreativitas antar anak, karya tersebut dapat menggambarkan kemampuan berpikir dan pengetahuan anak tentang wacana yang lebih komplek dibanding bila kegiatan bermain tersebut disetting oleh guru dalam bentuk penugasan.

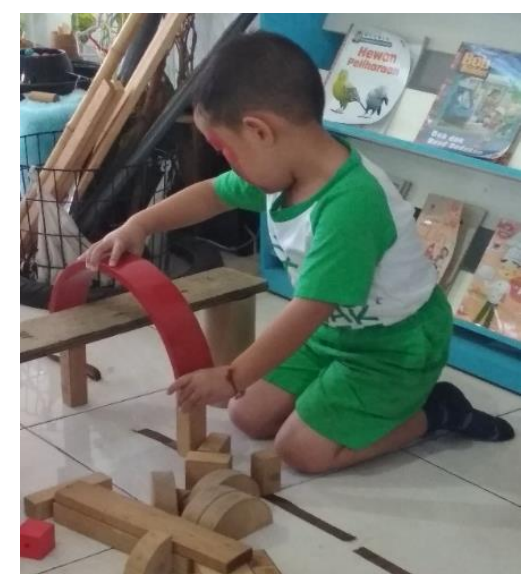

Gambar 4. Anak mengawali proyek membangun technopark sendirian (dokumen penelitian)

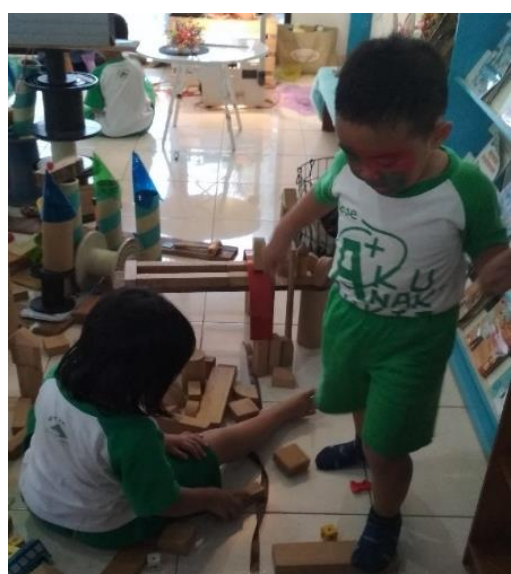

Gambar 5. Seorang teman menemani (dokumen peneliti)

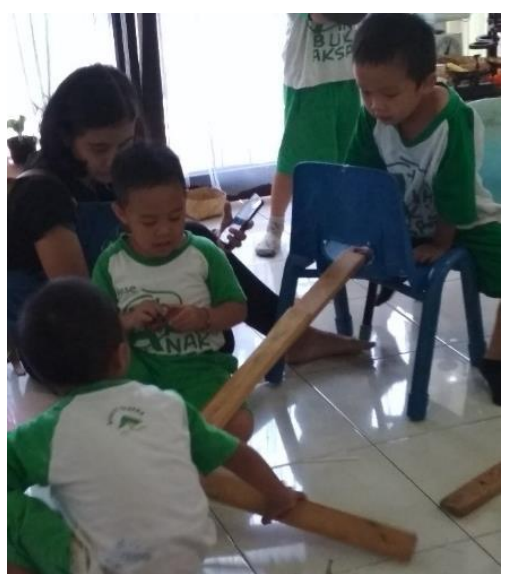

Gambar 6. Invitasi awal mulai diubah (dokumen penelitian)

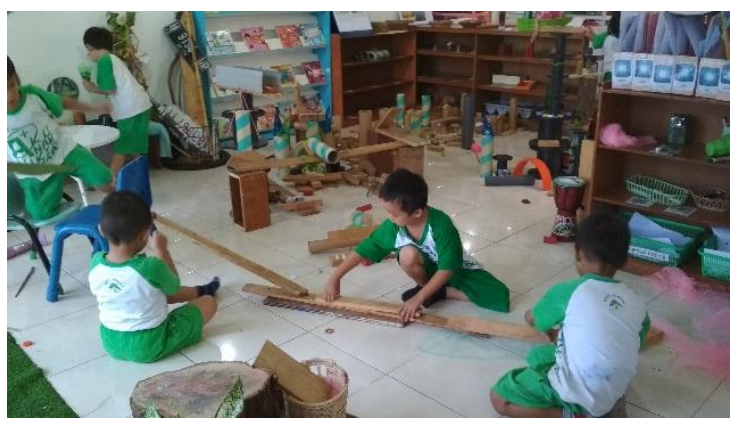

Gambar 7. Anak menambahkan bahan lepasan pada invitasi (dokumen penelitian)

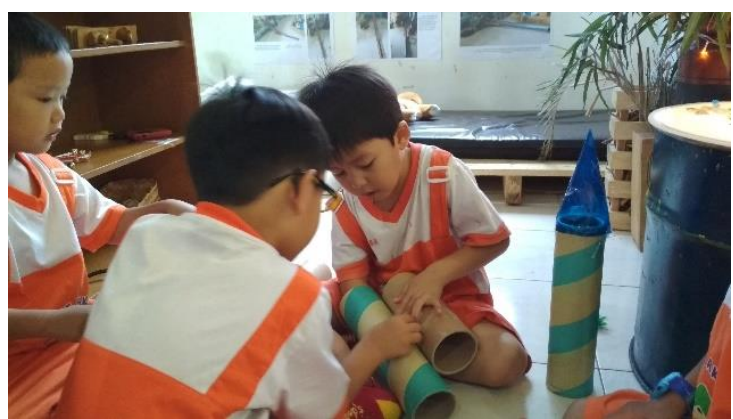

Gambar 8 Anak-anak sibuk menempelkan gelondongan untuk membuat senjata (dokumen penelitian)

Hal ini nampak pada sekelompok anak yang mengakses invitasi yang disiapkan Ibu guru pada hari yang berbeda. Invitasi tersebut terlihat sederhana, hanya berupa gelondongan berbahan kardus semacam gelondongan plastic atau atau tissue dapur. Juga ada gelondongan tissue biasa. Gelondongan ini ada yang berpola, ada yang polos. Sebelumnya, gelondongan ini merupakan proyek roket. Namun hari itu semua merasa roket tidak lagi bisa diperkaya dengan materi lain dan ada ide yang lebih menarik, membuat senjata roket yang nempel di tangan (lihat Gambar 8)

Anak-anak mengeksploitasi dan memanipulasi gelondongan dengan cara direkat menggunakan selotip plastic (lihat Gambar 9). Awalnya ada yang membuat pedang panjang dengan cara menempelkan gelondongan yang besar secara vertikal. Namun teman lain yang kemudian beranggapan akan lebih menarik membuat senjata yang bisa nembak tapi yang menyatu dengan tangannya. Mereka melakukan percobaan beberapa kali dengan merekatkan gelondongan-gelondongan tersebut pada tangan salah satu temannya namun selalu gagal saat senjata dicoba untuk digunakan. Gelondongan itu terlepas dari rekatannya. 


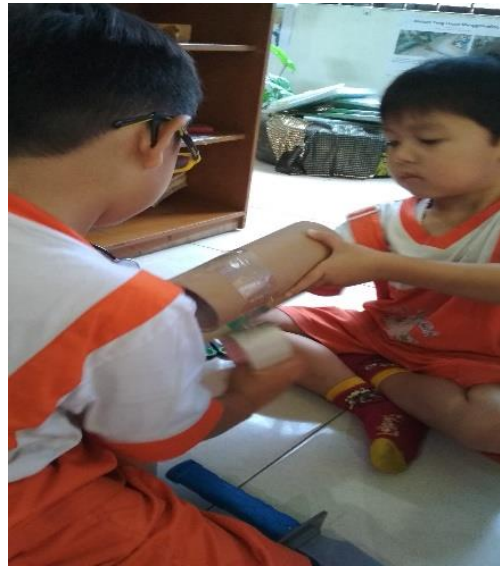

Gambar 9. Merekat dengan selotip besar (dokumen penelitian)

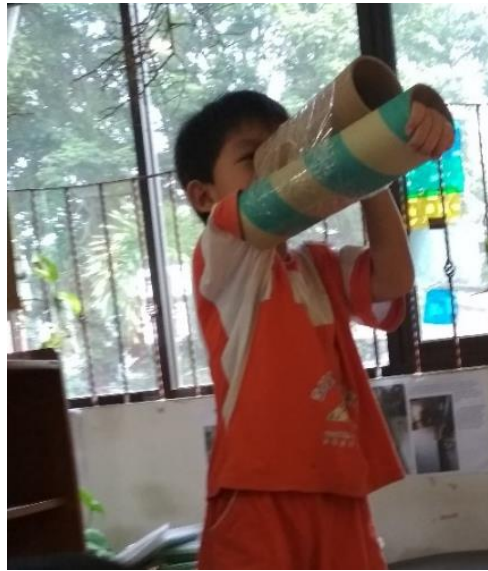

Gambar 10. Akhirnya berhasil membuat senjata yang menempel di tangan (dokumen penelitian)

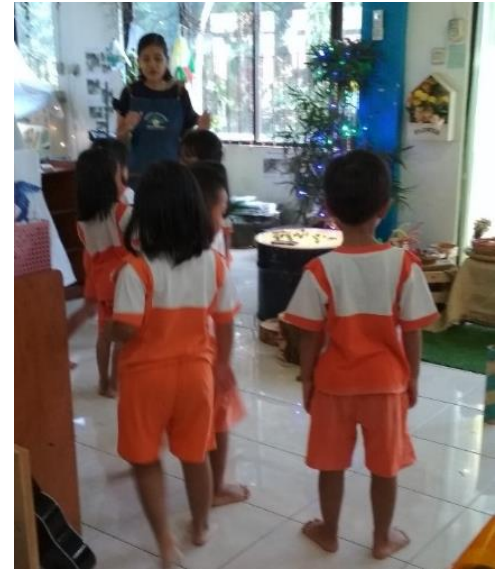

Gambar 11. Saat sebelum mulai kegiatan pembukaan (dokumen penelitian)

Sampai kemudian seorang teman yang lain yang memperhatikan kesibukan itu memberi saran untuk menggunakan selotip yang besar. Teman yang sedang tidak sibuk membantu menempel kemudian berlari untuk meminjam selotip plastik besar karena di kelas persediaan selotip plastik besar sudah habis. Dia menemukan selotip di atelier dan membawa kembali ke kelas pada dua temannya yang masih sibuk. Seorang teman membantu untuk memasangkan senjata dari gelondongan dengan selotip besar. Setelah beberapa saat, akhirnya tercipta senjata yang terpasang di tangannya (lihat gambar 10). Teman yang ikut membantu sejenak mengamati dengan lega, kemudian dia pun berpikir untuk membuat model senjatanya sendiri.

\section{Mengolah Bahan Lepasan, Melatih Perilaku Sosial}

Saat bermain bersama merupakan saat anak mengolah bahan lepasan untuk mewujudkan ide-ide kreatif mereka dengan cara mengeksplorasi, mengeksploitasi dan memanipulasi beragam benda. Saat itu anak berinteraksi dengan teman-temannya atau anak menunjukkan sejauh mana kematangan perkembangan sikap seperti kemandirian atau kemampuan bertanggung jawab atau rasa percaya dirinya.

Setiap hari sesudah kegiatan pembukaan, anak-anak mendapat kesempatan bermain selama dua jam. Bermain yang benar-benar bermain tanpa konsep yang dirancang oleh guru.

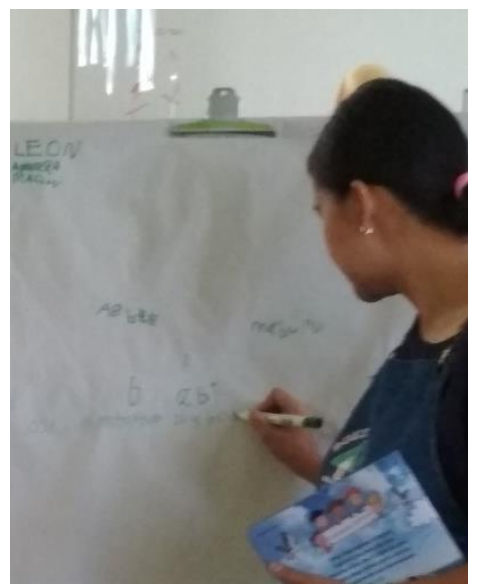

Gambar 12. Bu Guru membuat list kegiatan besok pagi (dokumen penelitian)

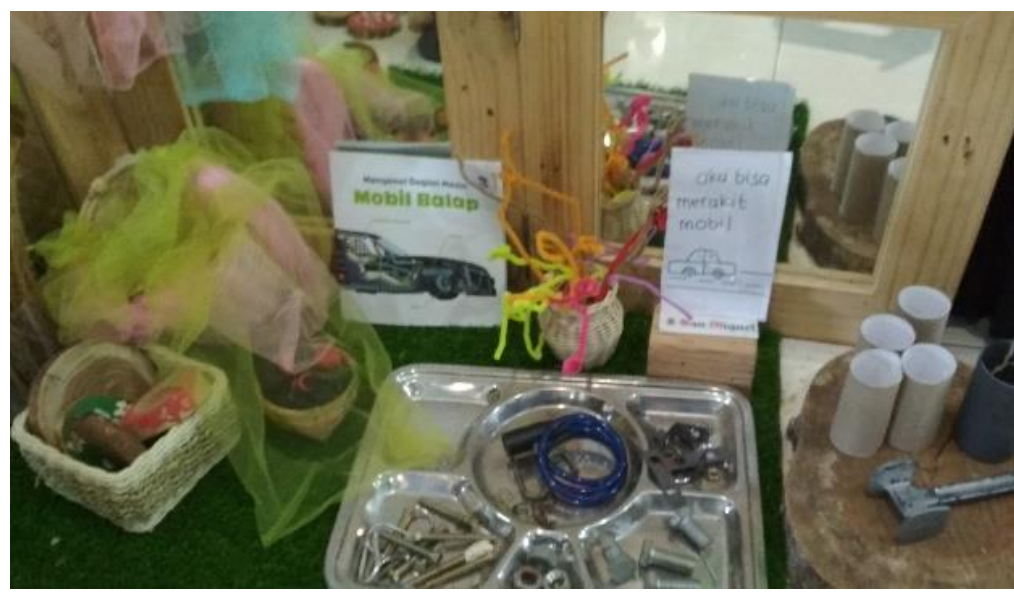

Gambar 13. Kain-kain yang memperkaya invitasi ini sebagian besar diambil dari atelier (dokumen penelitian) 
Setiap hari anak-anak memanfaatkan invitasi yang dibuat oleh bu Guru (lihat Gambar 12). Tak jarang mereka masih menambahkan dari beberapa atelier yang dimiliki sekolah. Atelier ini ruang penyimpanan bahan lepasan yang tidak mungkin dipajang keseluruhan di kelas (lihat Gambar 13). Atelier yang ada dalam ruang sekolah juga dimanfaatkan sebagai kelas, namun anak-anak yang ada di ruang tersebut paham jika benda-benda di ruang mereka dapat dipinjam oleh teman dari kelas lain.

Pagi itu beberapa anak membutuhkan benda yang harus diambil di atelier untuk menambah sirkuitnya. Anak-anak ingin memperpanjang jalur jalan dan memberi variasi. Kayu yang disandarkan Ibu Guru di salah satu pojok sebagai invitasi oleh kelompok yang lain. Seorang anak berinisiatif mengambil kayu lain dari atelier di halaman belakang.

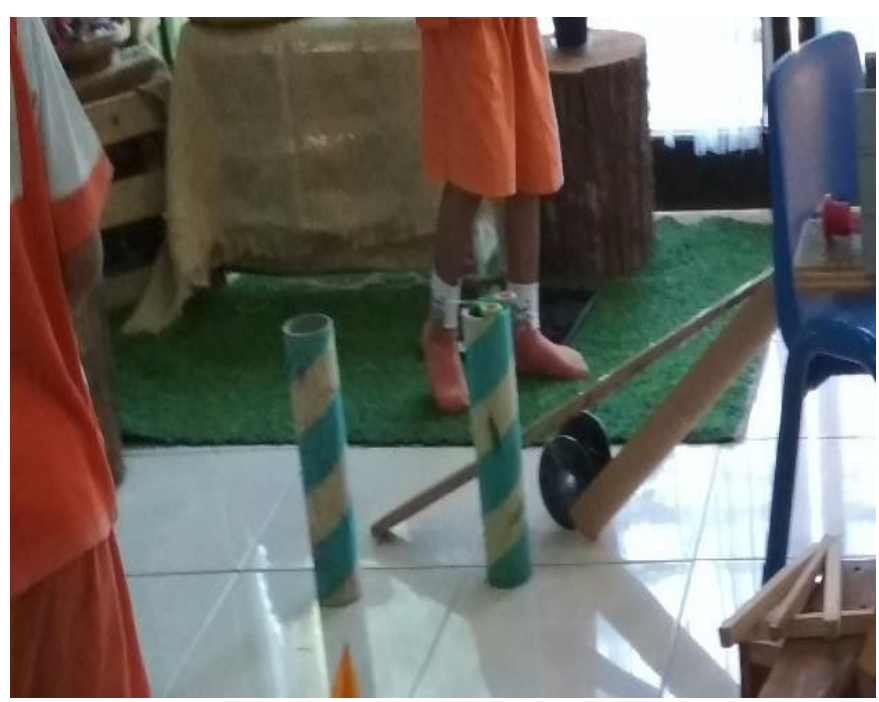

Gambar 14. Invitasi awal untuk sirkuit (dokumen penelitian)

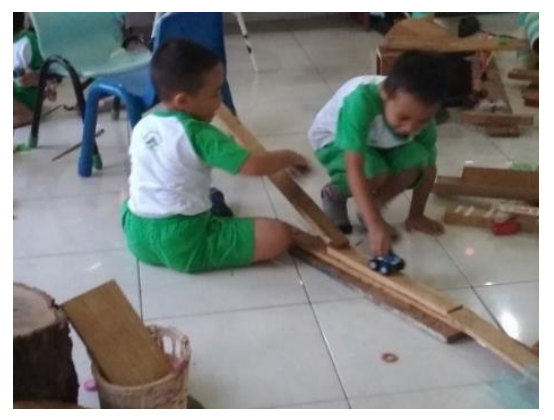

Gambar 16. Di hari lain, kayu ditambah karena model sirkuit berbeda dari yang awal (dokumen penelitian)

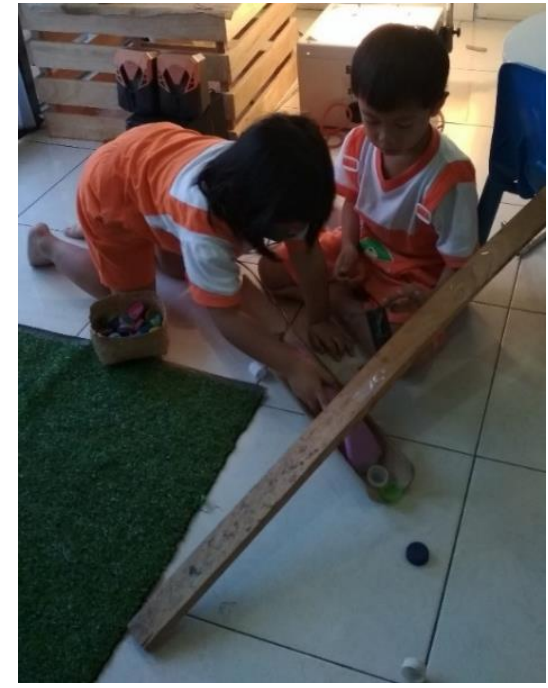

Gambar 15. Bambu disepakati pindah tempat untuk fungsi lain (dokumen penelitian)

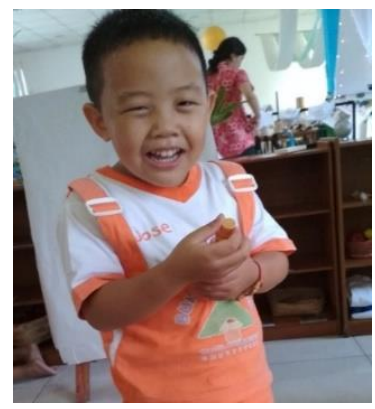

Gambar 17. Dengan ceria, anak menjelaskan fungsi air dalam botol yang dibawa (dokumen penelitian)

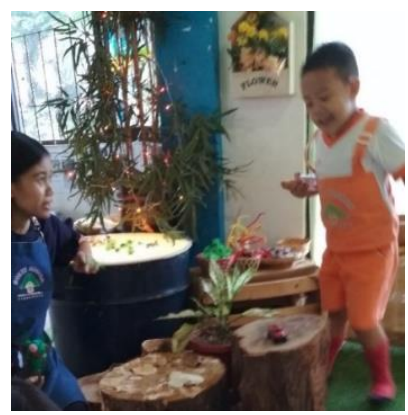

Gambar 18. Menjelaskan pada bu Guru perkembangan jamur yang baru saja disemprot air (dokumen penelitian)

Rasa percaya diri dan kemandirian anak tampak saat jam bermain maupun saat mendiskusikan kegiatan, baik sebelum usai jam belajar atau sebelum jam main. Saat bermain, rata-rata anak bermain dengan teman, entah satu orang atau lebih. Jarang sekali anak yang asyik bermain sendiri, meskipun selalu ada anak yang asyik dengan ide dan bermain sendiri untuk beberapa lama, namun tidak sepanjang waktu bermain yang tersedia. Paling tidak selalu ada teman yang menghampiri, entah sekedar mengamati atau bertanya apa yang sedang dikerjakan. 


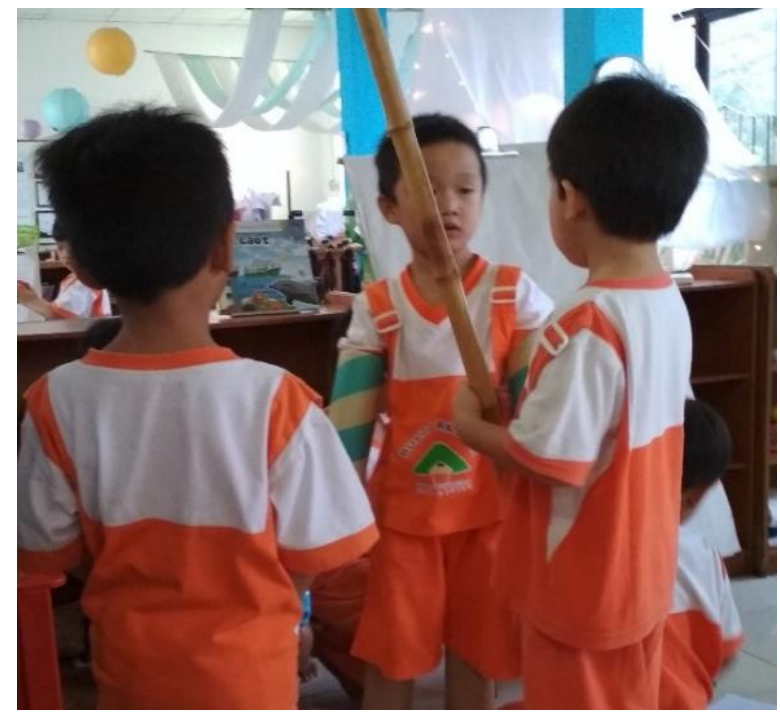

Gambar 19. Saling menceritakan ide tentang senjata yang akan dibuat (dokumen penelitian)

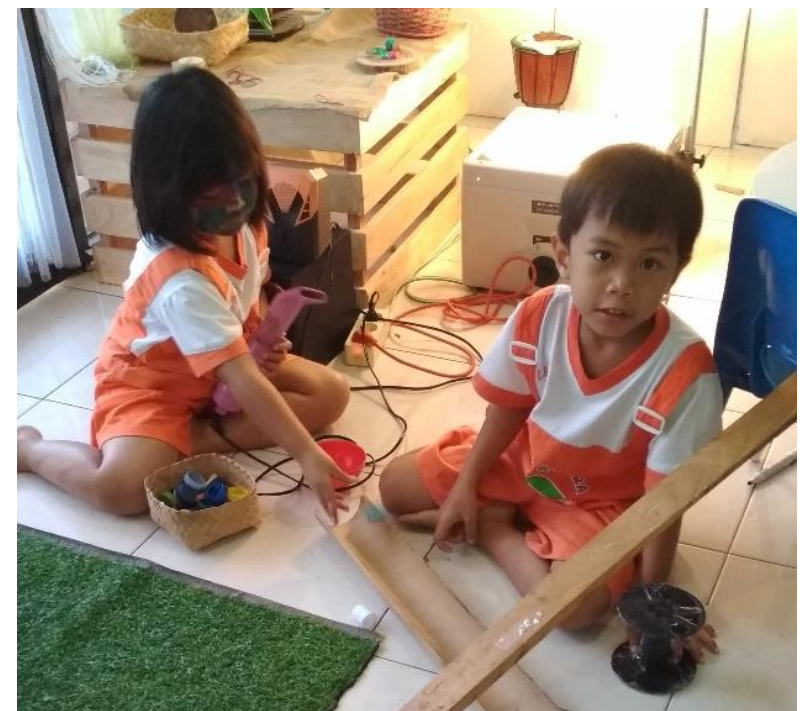

Gambar 20. Dengan percaya diri menggunakan alat elektronik asli secara mandiri untuk mengeksplorasi media (dokumen penelitian)

Seorang anak dengan percaya diri menjelaskan apa yang akan dikerjakan, saat ditanya tentang mengapa dia membawa botol berisi air, "Ini untuk menyiram jamur. Waktu sebelum libur kemarin, jamurnya masih bagus, sekarang ada yang sudah kering". Lalu dia menyemprot jamur yang ada di penampang potongan batang pohon. Bu Guru mendekati dan bertanya apakah dia masih akan melanjutkan untuk mengamati jamurnya. Anak mengiyakan. Bu Guru bertanya lagi, mengapa jamurnya ada yang seperti terpotong. Sambil tersenyumsenyum, anak itu menjawab, "Sepertinya jamurnya dimakan tikus". Ibu Guru seakan kaget mendengar jawabannya dan bertanya, "Darimana tikus bisa masuk ke sini dan memakan jamur?" Masih sambil tersenyum anak itu menjawab, "Itu di sana kan ada pintu (dia menunjuk pintu yang menuju ke halaman belakang), nah tikus masuk dari pintu. Lalu dia mencium bau jamur dan mencari. Terus ketemu jamur ini dan dia makan. Lalu tikus naik ke tembok dan keluar lewat pipa $\mathrm{AC}^{\prime \prime}$. Bu Guru memperhatikan keterangan itu dengan serius, kemudian mendongak ke atas melihat AC, "Tapi kabel AC tidak ada lubangnya". Anak itu menjawab lagi, "Ya berarti tikus sembunyi dulu. Dia keluar saat pintu ini dibuka", katanya sambil melihat pada pintu besar di kelasnya yang berfungsi untuk pencahayaan. Lalu dia beranjak pergi.

Rasa percaya diri dan kemandirian tampak berjalan seiring. Seorang anak yang memiliki rasa percaya diri yang baik terlihat mandiri dalam mengambil keputusan atau saat bekerja (bermain dengan media yang dipilih). Sebagian besar anak yang terlibat pada suatu kegiatan bermain dengan temannya tetap memiliki kemandirian dalam membuat keputusan atau melakukan pekerjaannya. Hal ini terbukti ketika anak selalu mampu menjawab saat ditanya apa yang akan dilakukan atau yang telah dilakukan. Anak tak segan juga untuk mencoba ide untuk satu kegiatan yang dimainkan bersama atau membantu mewujudkan ide teman.

Kemandirian anak juga nampak diiringi rasa tanggung jawab. Bahan lepasan yang digunakan sebagai media bermain di Bukit Aksara sebagian berbentuk barang asli, bukan berbentuk mainan tiruan. Misalnya peralatan pertukangan atau bengkel, merupakan bendabenda asli. Alat elektronik juga asli, sehingga menggunakan listrik untuk memfungsikan. Bila anak tidak dibiasakan bertanggung jawab, maka penggunaan benda-benda asli itu akan membahayakan diri sendiri atau orang lain. Anak bisa saja bermain dengan alat-alat tersebut tanpa pengawasan guru sebagai bentuk kemandirian namun dengan adanya rasa tanggung 
jawab akan keselamatan diri sendiri dan orang lain, anak dapat memainkan dengan prosedur yang benar dan terhindar dari bahaya.

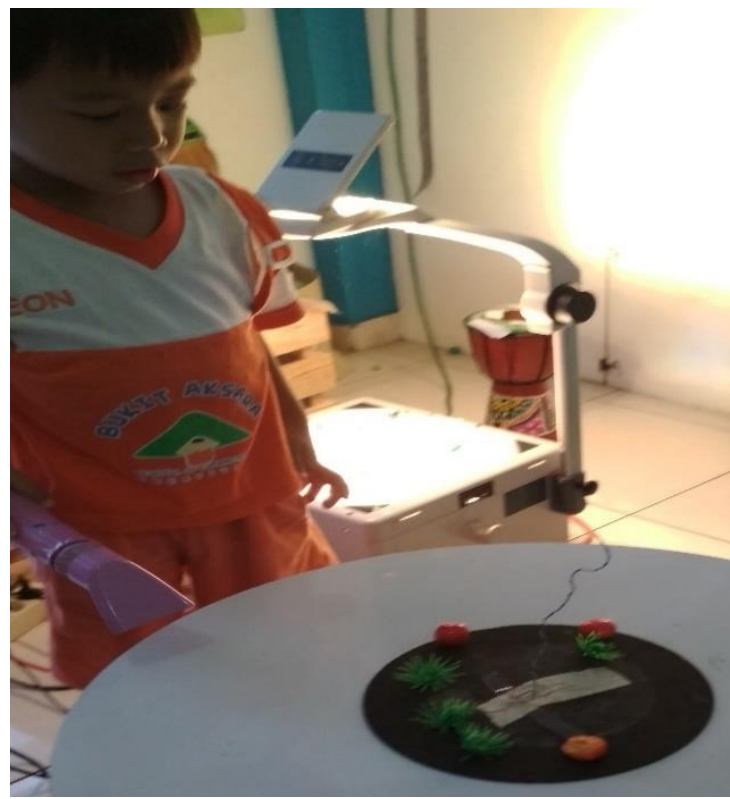

Gambar 21. Bermain dengan hairdriyer, membuktikan macam-macam benda yang mampu bergerak karena tiupan angin alat tersebut. (dokumen penelitian)

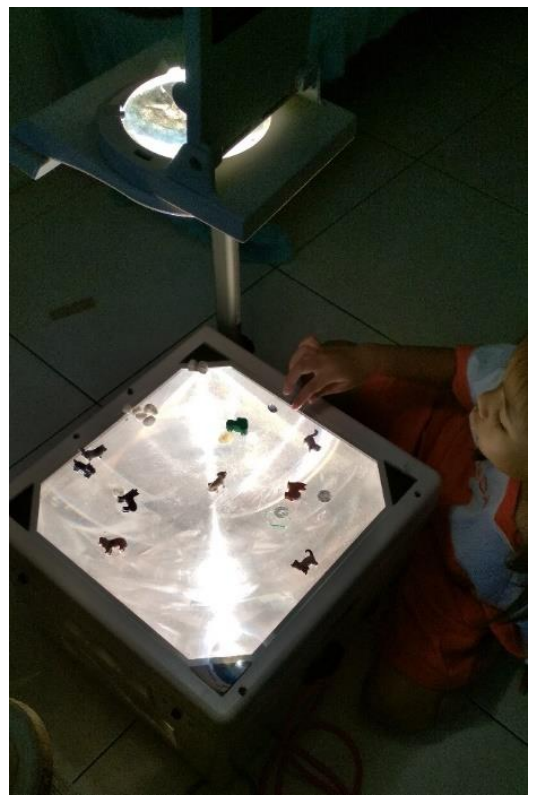

Gambar 22. Bermain wayang dengan OHP (dokumen penelitian)

Perilaku sosial merupakan salah satu karakterisrik dari keterampilan bermain (Ergin \& Ergin, 2017). Jika perilaku sosial yang positif meningkat dan yang negatif menurun maka keterampilan bermain anak juga akan meningkat. Perilaku sosial negatif seperti agresi fisik dan selalu memiliki perasaan tertekan, sedangkan perilaku sosial positif diantaranya kerjasama, percaya diri, tanggungjawab, dan kemandirian. Seluruh nilai-nilai ini muncul saat anak bermain bersama. Saat itu anak berinteraksi dengan teman-temannya atau anak menunjukkan sejauh mana kematangan perkembangan sikap seperti kemandirian atau kemampuan bertanggung jawab atau rasa percaya dirinya.

Kemampuan anak bekerja sama terlihat setiap harinya saat mereka mulai mengakses kegiatan bermain. Kegiatan yang dilakukan di TK Bukit Aksara yang menggunakan metode proyek dan bahan lepasan mendorong anak untuk saling bekerjasama membangun bangunan. Berdasar hasil penelitian, anak yang berada dalam metode proyek memiliki rasa kerjasama yang lebih baik dibandingkan dengan metode konvensional (Magta et al., 2019). Hal ini karena mereka didorong untuk lebih aktif memperoleh pengalaman belajar. Bukan guru yan menjadi pusat pembelajaran, namun obyek atau media dalam hal ini bahan lepasan yang menjadi pusat belajar anak.

Perilaku kerjasama juga tampak ketika seorang atau beberapa orang teman akan datang menyapa atau malah kemudian ikut intens terlibat pada kegiatan bermain yang sedang dilakukan oleh temannya. Mereka bisa saja mengembangkan ide yang sama atau saling mendukung. Namun ada juga yang bermain bersama namun memiliki ide yang berbeda. Kerja sama dapat terjadi meskipun ide tak selalu sama. Kerja sama diwujudkan dengan memunculkan resolusi terlebih dulu dengan membangun kesepakatan ide siapa yang akan diwujudkan lebih dulu. Hampir tidak ada seorang anak menghabiskan waktu sendirian untuk mengeksplorasi, mengeksploitasi atau memanipulasi bahan lepasan.

Saat bermain bersama merupakan saat anak mengolah bahan lepasan untuk mewujudkan ide-ide kreatif anak dengan cara mengeksplorasi, mengeksploitasi dan memanipulasi beragam benda. Situasi ini mendorong kemandirian anak dimana mereka tidak 
selalu bertanya atau bergantung pada oranglain tentang apa yang ingin mereka lakukan. Hal ini senada dengan penelitian yang menyatakan bahwa metode bermain dapat meningkatkan kemandirian anak (Basri et al., 2018). Guru perlu memberikan kesempatan bagi anak untuk memilih dan mencoba sesuai dengan keinginannya.

Lebih jauh, bermain menggunakan bahan lepasan juga dapat mendorong sikap tanggungjawab anak. Ketika anak mencoba bereksplorasi dengan bahan lepasan sesuai dengan idenya, mereka akan memilih bahan mana yang akan digunakan. Bahan lepasan yang dipilih oleh anak akan ia gunakan sebaik mungkin, bisa sesuai fungsi atau fungsi lain sesuai dengan imajinasinya. Poin penting di sini adalah mereka tidak merusak bahan tersebut. Paada saat iniplah proses pembetukan karakters bertanggungjawab terjadi. Anak berusaha menjaga agar bahan lepasannya bisa berfungsi dengan baik. Pembentukan karakter tanggungjawab harus mengacu pada perencanaan pembelajaran dan itu menjadi suatu keharusan yang disiapkan secara matang oleh guru (Haryani et al., 2019). Oleh karena itu, guru di kelompok A TK Bukti Aksara selalu menyiapkan bahan lepasan sehari sebelum pembelajaran dilakukan.

Peralatan pertukangan, alat-alat mekanik, alat elektronik tertentu yang digunakan pihak sekolah merupakan benda asli. Kondisi ini tentu mungkin akan dihindarkan untuk diakses anak pada sekolah lain karena dianggap memiliki tingkat membahayakan yang tinggi. Inilah salah satu keunikan lokasi penelitian ini, mereka berani menggunakan peralatan nyata. Meskipun demikian, pihak sekolah dan guru selalu melatih dan memperkenalkan sejak dini prosedur standar yang harus dipatuhi anak dengan penuh disiplin. Hal ini melatih anak bertanggung jawab serta memiliki rasa percaya diri yang dapat diandalkan oleh guru saat melepas anak untuk memainkan alat tersebut.

Selanjutnya, bahan lepasan yang disediakan sekolah harus dikelola oleh anak dalam arti sejak anak mulai mengakses hingga ketika dia mengakhiri proyek atau kegiatan bermainnya, anak bertanggung jawab atas keberadaan barang tersebut. Seperti saat menambahkan bambu sebagai sirkuit atau menggunakan crayon wajah untuk mencat wajah atau menggunakan tambahan benda-benda lain untuk membuktikan suatu ide, anak bertanggung jawab untuk mengembalikan semua benda tambahan yang dimainkan yang sudah tidak diperlukan dalam proyeknya ke tempat semula. Tanggung jawab anak nampak karena ketika waktu bermain hampir usai guru tidak perlu memerintahkan untuk mengembalikan benda-benda ke tempat semula setelah digunakan anak untuk bermain. Gusmaniarti \& Suweleh (2019) menyatakan Pentingnya sikap tanggung jawab untuk anak usia dini adalah sebagai dasar atau pondasi untuk kehidupan selanjutnya. Anak-anak dengan sendirinya mengembalikan permainan yang tidak dipakai dalam proyeknya kembali ke tempat semula.

Rasa percaya diri anak dapat meningkat ketika mereka diberikan kesempatan untuk melakukan demonstrasi (Nurmaniah, 2018). Ketika bermain bahan lepasan anak terlihat tenang, yakin akan idenya bagus dan menarik perhatian temannya, mampu menyesuaikan diri, dan menunjukkan sikap kreatif. Mereka mencoba menunjukkan kepada orang lain proyek, benda, atau bangunan apa yang telah dibuat dengan rasa bangga.

Bermain menggunakan bahan lepasan juga termasuk bermain peran. Hasil penelitian menunjukkan bahwa bermain peran dapat meningkatkan rasa percaya diri anak (Aryenis, 2018). Ketika bermain bahan lepasan, anak membangun skybridge, technopark, dan senjata. Setelah selesai menjadi sebuah bangunan atau benda, mereka memainkan seolah-olah itu nyata. Imajinasi mereka terus bergerak menggunakan berbagai media yang telah dibuat. Uniknya, media tersebut dibuat sendiri oleh anak menggunakan berbagai bahan lepasan yang dipasang atau direkatkan menjadi bentuk baru.

Bentuk - bentuk perilaku sosial seringkali muncul dengan sendirinya ketika anak "tenggelam" dalam kegiatan bermainnya. Merangkai bahan lepasan tidak saja menjadi wadah berinteraksi, namun menjadi sarana tepat anak untuk mengembangkan beragam bentuk perilaku sosial. Tahapan bermain dimulai sesaat setelah anak mengamati invitasi atau melanjutkan proyek yang sudah dibuatnya atau membuat proyek baru. Jarang terjadi seorang 
anak benar-benar tidak terlibat menggunakan bahan lepasan untuk mengolah ide dan dorongan kreativitasnya.

Pengaturan kelas dapat diatur sedemikian rupa untuk menghindari masalah-masalah potensial dan mengembang-kan ke-tersediaan dukungan bagi anak untuk ber-interaksi sesuai pilihan dan keinginannya (Casey \& Carter, 2016). Bermain pada dasarnya melakukan gerak fisik. Pengaturan kelas berkaitan dengan pertimbangan agar anak dapat bergerak dengan bebas saat bermain. Anak usia dini belajar dengan baik melalui bermain. Disamping itu belajar melalui bermain, melibatkan anak dalam kegiatan bermain dan belajar, bercerita atau mendongeng dapat dijadikan kontribusi dalam mengenalkan konsep dasar literasi pada anak (Fahmi et al., 2020). Selain itu menyediakan beberapa pilihan kegiatan dalam bentuk beragam invitasi menggunakan bahan lepasan menjadi bentuk reinforcement yang positif dan menjadi dasar untuk menguatkan anak agar lebih terlibat dalam kegiatan bermain yang mungkin sebelum tidak mereka rencanakan atau inginkan.

Pada saat menjawab pertanyaan Ibu Guru tentang rencana kegiatan bermain yang akan dilakukan, anak melakukan dengan rasa percaya diri. Mereka juga mandiri dalam menentukan sikap untuk menjawab alasan apakah mereka akan melanjutkan kegiatan atau akan bermain sesuatu yang baru. Percaya diri dan tanggung jawab berhubungan erat dengan kemandirian. Ketika anak memahami tugas yang menjadi tanggung jawab mereka, anak mengembangkan rasa percaya diri dan kemandirian secara bersamaan. Keterlibatan anak merancang, memilih, membangun dan mewujudkan idenya menggunakan media bahan lepasan menjadi sarana menjalin interaksi sosial dengan teman sebaya. Yulianti (2014) anak yang cenderung berani mengambil resiko mampu beradaptasi dengan lingkungan dan tidak pemalu dapat mengekspresikan dirinya dengan optimal karena rasa percaya dirinya yang tumbuh sehingga kreativitasnya dapat berkembang. Konstruksi bentuk perilaku sosial dapat terjadi karena tersedianya kesempatan anak untuk memilih kegiatan apa yang dapat membuat mereka berkembang. Kesempatan memilih kegiatan bermain yang berbeda merupakan sarana yang efektif untuk mereduksi perilaku yang kurang tepat dan meningkatkan keterlibatan kerja sama anak (Casey \& Carter, 2016). Kelemahan dari penelitian ini adalah belum diketahui perbedaan perilaku sosial yang ditinjau dari berbagai faktor seperti gender, latar belakang keluarga, dan kesehatan anak. Peneliti selanjutnya perlu mencari tahu bagaimana perbedaan perilaku sosial tersebut ketika menggunakan bahan lepasan.

\section{SIMPULAN}

Kesempatan yang dimiliki oleh anak untuk mengolah bahan lepasan secara mandiri dapat mempermudah pengembangan perilaku sosial seperti tanggung jawab, kemandirian, kerja sama, dan rasa percaya diri. Perilaku tanggungjawab terjadi ketika anak-anak menjaga bahana lepasan agar tetap bisa berfungsi dengan baik. Perilaku kemandirian terjadi ketika anak berusaha mengolah bahan lepasan menjadi bentuk yang mereka inginkan. Perilaku percaya diri terjadi ketika anak mengimplementasikan idenya dalam berbagai bentuk dan yakin bahwa idenya itu menarik. Perilaku kerjasama terjadi ketika anak-anak saling membantu mengerjakan proyek atau mengolah bahan lepasan sesuai idenya meskipun berbeda satu sama lainnya.

\section{DAFTAR PUSTAKA}

Aryenis, A. (2018). Peningkatan Rasa Percaya Diri Anak Melalui Kegiatan Bermain Peran Di Taman Kanak-Kanak Restu Ibu. Jurnal Ilmiah Pesona PAUD, 5(2), 47-60. https:// doi.org/10.24036/103726

Basri, H., Islam, F. A., \& Gresik, U. M. (2018). Pengaruh metode bermain kelompok dalam meningkatkan kemandirian anak pada siswa kelompok bermain muslimat nu 102 nurul huda di desa samirplapan duduk-gresik. Jurnal TAMADDUN, XIX(2), 149-156.

Casey, L. B., \& Carter, S. L. (2016). Applied behavior analysis in early childhood education: An 
introduction to evidence-based interventions and teaching strategies. In Applied Behavior Analysis in Early Childhood Education: An Introduction to Evidence-based Interventions and Teaching Strategies. https://doi.org/10.4324/9781315775371

Ergin, B., \& Ergin, E. (2017). The Predictive Power of Preschool Children's Social Behaviors on Their Play Skills. Journal of Education and Training Studies, 5(9), 140. https:// doi.org/10.11114/jets.v5i9.2601

Fahmi, F., Syabrina, M., Sulistyowati, S., \& Saudah, S. (2020). Strategi Guru Mengenalkan Konsep Dasar Literasi di PAUD Sebagai Persiapan Masuk SD/MI. Jurnal Obsesi : Jurnal Pendidikan Anak Usia Dini, 5(1), 931-940. https:/ / doi.org/10.31004/obsesi.v5i1.673

Gusmaniarti, G., \& Suweleh, W. (2019). Analisis Perilaku Home Service Orang Tua terhadap Perkembangan Kemandirian dan Tanggung Jawab Anak. Aulad: Journal on Early Childhood, 2(1), 27-37. https:/ / doi.org/10.31004/aulad.v2i1.17

Haryani, R. I., Jaya, I., \& Yulsyofriend. (2019). Pembentukan karaker tanggung jawab di taman kanak-kanak Islam Budi Mulia Padang. Jurnal Ilmiah Potensia, 4(2), 105-114.

Henniger, M. L. (2013). Teaching young children: An introduction, 5th edition. In USA Education. Inc:Pearson (5 ed.). Pearson Education, Inc.

Khalfaoui, A., García-Carrión, R., \& Villardón-Gallego, L. (2021). A Systematic Review of the Literature on Aspects Affecting Positive Classroom Climate in Multicultural Early Childhood Education. In Early Childhood Education Journal (Vol. 49, Nomor 1, hal. 7181). Springer Netherlands. https:// doi.org/10.1007/s10643-020-01054-4

Magta, M., Ujianti, P. R., \& Permatasari, E. D. (2019). Pengaruh Metode Proyek Terhadap Kemampuan Kerjasama Anak Kelompok A. Mimbar Ilmu, 24(2), 212. https:// doi.org/10.23887/mi.v24i2.21261

Nurmaniah, N. (2018). Upaya Meningkatkan Kepercayaan Diri Anak Usia 5-6 Tahun Melalui Metode Demonstrasi Di PAUD Binika Desa Sukaramai Kab. Langkat. JURNAL DIVERSITA, 4(1), 52. https://doi.org/10.31289/diversita.v4i1.1601

Pebriana, P. H. (2017). Analisis Penggunaan Gadget terhadap Kemampuan Interaksi Sosial. Jurnal Obsesi: Jurnal Pendidikan Anak Usia Dini, 1(1), 8. https:// doi.org/10.31004/obsesi.v1i1.26

Sari, C. R., Hartati, S. H., \& Yetti, E. (2019). Peningkatan Perilaku Sosial Anak melalui Permainan Tradisional Sumatera Barat. Jurnal Obsesi : Jurnal Pendidikan Anak Usia Dini, 3(2), 416. https:// doi.org/10.31004/obsesi.v3i2.225

Siantajani, Y. (2020). Loose Parts Material Lepasan Otentik Stimulasi PAUD. In PT Sarang Seratus Aksara. PT Sarang Seratus Aksara.

Wahyuningsih, S., Pudyaningtyas, A. R., \& Nurjanah, N. E. (2017). Pemanfaatan Loose Parts Dalam Pembelajaran Steam. Early Childhood Education and Development Journal, 2(10), 15.

Yulianti, T. R. (2014). Peranan Orang Tua Dalam Mengembangkan Kreativitas Anak Usia Dini. Jurnal Empowerment, 4(1), 11-24. http://ejournal.stkipsiliwangi.ac.id/index.php/empowerment/article/view/569 